\title{
MUSEU CASA DE CORA CORALINA E O LUTO ESTRATIFICADO EM MEMÓRIAS FEMININAS
}

\author{
Clovis Carvalho Britto' \\ Paulo Brito do Prado²
}

\section{Resumo}

O artigo tece algumas considerações sobre o luto estratificado em memórias femininas e o gênero a partir de fotografias fúnebres guardadas na reserva técnica do Museu Casa de Cora Coralina, na cidade de Goiás. $\mathrm{Na}$ produção de nossa argumentação partimos da musealização da memória do luto depositado em fotografias guardadas por Jacintha Luiza do Couto Brandão e Cora Coralina entre fins do século XIX e o século $X X$. Deste estudo observamos que a guarda exercitada por mulheres é atravessada por marcas de gênero em que a construção histórica do leque de simbolismos sexuais impôs a elas tarefas relativas à exteriorização da dor e da perda. Deste modo consideramos que o gênero operou em muitos seguimentos da vida social de mulheres viúvas, obrigando-as a tornarem-se responsáveis, dentre várias coisas, pela memória de seus mortos.

Palavras-chave

Mulheres. Gênero. Luto. Museologia. Museu Casa.

\begin{abstract}
The article presents some considerations about the mourning stratified in female memories and the genre from funeral photographs stored in the technical reserve of the Museu Casa de Cora Coralina in the city of Goiás. In the production of our argument we start from the musealization of the memory of the mourning deposited in photographs kept by Jacintha Luiza do Couto Brandão and Cora Coralina between the end of the 19th and the 20th century. From this study we observe that the guard exercised by women is crossed by gender marks in which the historical construction of the range of sexual symbolism imposed on them tasks related to the exteriorization of pain and loss. In this way we consider that the genre operated in many segments of the social life of widowed women, forcing them to become responsible, among many things, for the memory of their dead.
\end{abstract}

\section{Keywords}

Women. Gender. Mourning. Museology. House Museum.

Pobre, vestida de cabelos brancos, voltei à velha Casa da Ponte, barco centenário encalhado no Rio Vermelho, contemporânea do Brasil Colônia, de monarcas e adventos. Ancorada na ponte, não quiseste partir rio a baixo, agarrada às pedras. Nem mesmo o rio pode te arrastar, raivoso, transbordante, lavando tuas raízes profundas a cada cheia bravia, velha casa de tantos que se foram.

I Doutor em Sociologia pela Universidade de Brasília. Professor do bacharelado em Museologia da Universidade de Brasília e do Programa de Pós-Graduação em Museologia da Universidade Federal da Bahia. E-mail: clovisbritto5@hotmail.com

2 Doutorando em História Social pelo Programa de Pós-Graduação em História Social da Universidade Federal Fluminense. E-mail: paulobritogo@yahoo.com.br 


\section{Museu Casa de Cora Coralina e o luto estratificado em memórias femininas}

Ainda vive e pulsa aqui teu coração imortal, testemunha vigilante do passa-

do. Humilde, pequenina e ofertante, a biquinha d'água, generosa, indiferente

à decadência, a biquinha anciã de águas puras de ignota mina. Cantante e fria, correndo sempre menina na sua calha de aroeira. Biquinha, és banho e refrigério, copo de água cristalina e azul para a sede de quem fez longa caminhada às vertentes do passado e volta vazia às origens da sua própria vida.

Casa Velha da Ponte, és para o meu cântico ancestral uma bênção madrinha do passado.

Cora Coralina (1976: 93, grifos nossos)

Optamos principiar a caminhada pela memória do luto encerrado no Museu Casa de Cora Coralina, em Goiás-GO, partindo da própria casa. Barco centenário encalhado no Rio Vermelho, ancorada na ponte e agarrada às pedras, a velha casa de tantos que se foram, testemunhou passados, acolheu temporalidades e converteu-se em depositária dos estratos do tempo (Koselleck, 20I4).

Entendemos a confluência de temporalidades no Museu Casa de Cora Coralina mediante a categoria de "estratos do tempo" e que segundo Reinhart Koselleck são vestígios de "experiências acumuladas por indivíduos e gerações contemporâneas" (20|4: 23). O manuseio desta categoria, acompanhada de outras metáforas da memória, permite-nos compreender não haver oposição entre o linear e o circular. Isto porque ao voltarmos nossa atenção para o museu e para a presença de memórias enlutadas conferimos que os tempos históricos, na verdade, "consistem em vários estratos que remetem uns aos outros, mas que não dependem completamente uns dos outros.” (2014: 19-20)

Como um palimpsesto, a Casa da Ponte transfigurou-se em "velho documentário de passados tempos, vertente viva de estórias e de lendas" (Coralina, 1976: 91) que até hoje embalam o imaginário e a memória social dos goianos (Britto; Seda, 2009). Em poesias e crônicas, Cora Coralina (I889-I985) exercitou a evocação de memórias que permaneciam acumuladas na Casa da Ponte. Ao ancorar seus escritos nestas memórias, ela permitiu o trânsito de diferentes estratos do tempo e, vez ou outra, fez da casa uma ponte entre a vida e a morte. A metáfora de palimpsesto que manejamos é a mesma utilizada por Sandra Jatahy Pesavento (2005) e Aleida Assmann (20I I). Para elas, a metáfora retirada do exercício de sobreposição de anotações e registros escritos em pergaminhos entre os séculos VII e IX, como estratégia de aproveitamento do papel, permite o entendimento da sobreposição de tempos e de memórias que permanecem e, muitas vezes, saltam para fora das águas do tempo em que permaneciam acumuladas.

Em "Casa Velha da Ponte”, parcialmente apresentada na epígrafe e no fragmento que se segue, Cora demonstrou o potencial ancestral deste lugar e o acúmulo de reminiscências diretamente relacionadas ao luto e à morte: 
Portugal, prevaricador da Real Coroa, sonegador e esbanjador dos Quintos de El Rei, bebeu seu copo de veneno, tendo antes feito beber ao seu antigo escravo de confiança, que muito sabia e podia contar. Depois veio um Sargento-mor, bisavô de muitos, português colonial. Um Cônego Couto, liberal e dono de moedas, montes de ouro, prataria. Contava minha bisavó que esse senhor Cônego, feito suas Humanidades em Coimbra, só almoçava sua gorda feijoada goiana em pratos e talheres de ouro. Um capitão da guarda nacional, que dragonou milhares de homens felizes e analfabetos, capitães, majores e coronéis, enfeitados com galões dourados e vitalícios sem percalços de reforma. Um desembargador da Monarquia - meu pai -, minha mãe viúva. Minhas irmãs, eu, afinal a última sobrevivente de gerações passadas. (Coralina, 1976: 91)

A Casa Velha da Ponte figura-se na literatura de Cora Coralina como um lugar de deslocamentos. Sua condição histórica remete ao trânsito entre diferentes marcadores adventícios. Sua "ancianidade vigorosa e sã" (1976: 90) denuncia ser ela uma ponte que liga juventude e velhice, vida e morte, luto e saudade, início e fim. Construída nos tempos da Colônia, a casa atravessou o Império, percorreu os tempos da República e metamorfoseou-se, no presente, em museu, em ancoradouro de muitas memórias e várias histórias.

A Casa de Cora Coralina, anteriormente casa de Jacintha Luiza e de tantas/os outras/os é espaço em que muitas vidas começaram e findaram. É lugar de intermezzo, ponto de intersecção de vários estratos do tempo; armazenadora e meio de muitas memórias e temporalidades sobrepostas umas sobre as outras (Pesavento, 2005). Entendida aqui como espaço de recordação (Assmann, $20 \mathrm{II}$ ) a casa integra a paisagem urbana de Goiás em que diferentes agentes deixaram suas marcas e legaram vestígios de suas experiências.

Ao reativar memórias acumuladas no interior da casa e na "biquinha anciã de águas puras de ignota mina”, Cora fez uso da metáfora da água como força regenerativa e profética (Assmann, 20I I). Embora a água tenha um significado ambivalente, pois, reportando à Antiguidade Clássica, associa-se ao rio Lete e seu "fluxo que varre irremediavelmente tudo que há e nos separa de fases anteriores de nossa existência, tal como o rio Estige nos separa da própria vida" (201 I: I84), em Cora a água que mata sua sede de memória jorra de uma fonte sagrada, uma fonte que a impede de esquecer.

Ao beber da biquinha, Cora acionou antigas lembranças, inquietantemente guardadas por mulheres viúvas e que terminaram seus dias na casa. Ela própria, ao retornar de São Paulo quarenta e cinco anos depois, converteu-se em uma evocadora de memórias. Cora foi a "última sobrevivente de gerações passadas" que transitaram pela Casa Velha da Ponte.

A água converteu-se em dispositivo acionador de antigos espíritos.Após retornar vazia às origens de sua própria vida e tomar "um gole da fonte das musas" (Assmann, 201 I: 185) Cora reativou a memória de sua bisavó. Uma memória feminina e que aludia aos primeiros moradores da casa:Thebas Ruiz; seu bisavô, o Cônego Couto; os capitães da guarda nacional e seu pai, o desem- 
Museu Casa de Cora Coralina e o luto estratificado em memórias femininas

bargador da Monarquia, Francisco de Paula Lins dos Guimarães Peixoto (Britto; Seda, 2009).

A biquinha que correu/corre "sempre menina na sua calha de aroeira" permitiu à escritora reativar a memória de antigos moradores. Segundo ela estas reminiscências só foram preservadas graças ao trabalho de memória de suas bisavós, avós e mãe viúva. Para Cora foram todas estas mulheres que impediram o total recalque de estratos do tempo e de fatos que preenchem parte importante do imaginário coletivo da cidade de Goiás.

\section{"Minha mãe muito viúva"}

A memória do luto estratificado no museu casa remete ao exercício de guarda das fotografias funéreas e objetos em que Jacintha Luiza do Couto Brandão e Cora Coralina (Anna Lins dos Guimarães Peixoto Brêtas) ancoraram a memória de seus familiares já falecidos, talvez na intencionalidade de guardar e velar o luto, afagar a dor de perdas familiares ou o fato de terem sido as últimas moradoras da casa antes de ela ser musealizada (processo composto por uma série de ações sobre os objetos - aquisição, pesquisa, conservação, documentação e comunicação). (Cury, 2005)

Sobre tal questão as anotações no verso da fotografia fúnebre enviada por Cora, em 1918, na expectativa de que sua mãe, Jacintha Luiza, a guardasse, dão algumas pistas:

\footnotetext{
Mãe.

Remetto-Ihe este retrato da sua netinha Maria Isis, morta em 24 de novembro do anno passado. Como a sra. perceberá facilmente o retrato esta muito mal tirado e exagerado, pois ella sempre foi muito miudinha, nunca cresceu, nunca teve saúde.

Guarde-o como uma piedosa recordação da neta morta e da filha ausente.
}

Abraços saudosos da

Annica

Jaboticabal, $19-08-918^{3}$.

Este registro denuncia o caráter piedoso creditado à mulher em uma sociedade fortemente influenciado pela tradição cristã. Tradição esta que agia de modo a mantê-la alheia às diferentes questões relativas ao mundo dos homens. Tal estratégia desenvolvida no interior das relações entre os sexos reporta aos séculos XIX e XX.

O século XIX foi o "primado da palavra masculina [e que] não se

3 Acervo do Museu Casa de Cora Coralina, Goiás-GO. 
desmente na retórica [da] copiosa produção de modelos [de mulher]" (Giorgio, 1991: 206). Segundo Michela de Giorgio, "o progresso do sentimentalismo religioso no século XIX esta em estreita relação com o sentimentalismo familiar: 0 modelo feminino católico é exclusivamente o da esposa e da mãe" (I99|: 206). Por conseqüência, restou às mulheres "a prática de um 'contra discurso' fundado essencialmente nas características da sua religiosidade. Uma religiosidade 'sentimental' que dos lugares da devoção se [estendeu] ao quotidiano familiar" (199I:206). Mas que, enfatizamos, não era utilizado de forma passiva, conforme planejado pelas instituições de poder.

A Igreja, a piedade e a religiosidade foram manejadas pelas mulheres de modo a lhes permitir forçar passagem e sair para desenvolver suas influências junto às portas do poder (Perrot, 2005).

Como Jacintha Luiza permaneceu em Goiás e passou seus últimos dias na Casa da Ponte, possivelmente ficou encarregada de guardar a memória de seus familiares e o luto daqueles que muito cedo partiram. $A$ incumbência de Cora à Jacintha reforçou aquilo que registrou em "Papéis de circunstância". No momento em que se referia à Jacintha, Cora a destacou como uma mulher muito viúva, frustrada e desgostosa da vida:

\begin{abstract}
Minha mãe desiludida, na sua dupla viuvez, vivia vida sedentária, passava os dias mergulhada na leitura do 'Jornal do Comercio' e do 'Paiz' ou de grandes volumes encadernados do "Panorama" numa transferência ou evasão de suas frustrações de mulher.Tinha atitude de pessoa 'desgostosa da vida', como se dizia então. Apegava-se, também, com interesse resignado e tranquilo ao feito de um crochê muito largo, de linha muito fina, de ponto muito aberto, com ramos de rosas, lírios, folhas e cachos de uvas que nunca vi terminado. (Coralina, 2006: 94)
\end{abstract}

Jacintha Luiza parecia reunir em si um acúmulo de lutos e que, conforme contou sua neta, Ondina de Bastos Alberrnaz, era "quase que oficializado e obrigatório" (1992: 33).Viúva por três vezes caberia à Jacintha usar "luto fechado por um período de dois anos, e luto abreviado por tempo indeterminado" (1992: 34). Este era o costume do luto na cidade de Goiás entre fins do século $\mathrm{XIX}$ e meados do $\mathrm{XX}$.

Conforme notado nas referências comportamentais de Jacintha, registradas por Cora, ela parece ter feito o luto, as frustrações da vida e a morte espraiarem-se por sua trajetória. Apontamos tal impressão, pois em consulta aos seus registros de leitura no Gabinete Literário Goiano, entre 1900 e 190I, notamos ter ela direcionado sua atenção para livros que evocavam a morbidez, a morte e o luto. Neste período Jacintha Luiza leu "Viúva milionária", "Anjos da Terra", "Toutinegra da Manhã”,"Memórias do Diabo", “Collar do Diabo”,"A freira enterrada em vida", "Catacumbas de Paris”,"Mai dos desaparecidos" e "A 
Museu Casa de Cora Coralina e o luto estratificado em memórias femininas

relíquia"4. Todos esses livros evocavam a morte e a dor da perda de algum ente familiar.

Ainda sobre a guarda do luto, Cora registrou que sua mãe,"muito viúva, isolava-se no seu mundo de frustrações" (Coralina, 2007: I I6) e quando não estava lendo encadernados de jornais nacionais e estrangeiros ou a "História Universal de César Cantu em doze volumes" (2006: 95), guardava "roupas pretas de elascotine inglesa - croisé, colete de trespasse, calça afunilada - carregada de fivelas - de gente antiga que tinha morrido há muito tempo de febre amarela" (2006: 88), ou o retrato de um de seus maridos. Sobre isto, Cora destacou que:

\begin{abstract}
$\mathrm{Na}$ outra parede, um retrato de homem moço e romântico, tipo definido de tuberculoso antigo com uma barbica rala no queixo e penugens pelo mento, um bigode fraco e triste, colarinho largo, gravata de retrós, colete de trespasse, cabelo à Carlos Gomes, tendo em cima uma coroa mortuária de biscuí com suas fitas escuras pendentes e letras douradas se despregrando, dizendo o desconsolo da viúva, velado de uma escumilha preta e tendo atravessado por cima uma pluma rala de cor roxa, muito fúnebre. Era o primeiro marido de minha mãe e que ai ficara esquecido e inofensivo depois do seu casamento com meu pai. (Coralina, 2006: 92-93)
\end{abstract}

As notícias apresentadas por Cora acerca da guarda do luto e de suas experiências deixam ver como ela e sua mãe, cada uma em seu tempo, guardaram memórias marcadas pelo luto e cultivaram lembranças da saudade, vestígios de tempos em que as mulheres, impedidas de figurar em ambientes públicos, a exemplo dos lugares em que se velava o morto, "inteiramente cobertas de negro, mater dolorosa, apareciam aos olhos do mundo apenas como o símbolo da dor e do desconsolo." (Ariès, 20I 2: 23I)

Lembramos que mesmo marcadas pela tradição cristã, em constante processo de metamorfose entre os séculos XIX e XX, as mulheres foram, "na cidade, espaço sexuado deslocando, pouco a pouco, as fronteiras entre os sexos" (Perrot, 1998: 37). Elas foram:

Caminhando na contra mão da 'dominação masculina' e criando contra poderes, ou poderes simbólicos que viessem lhes permitir ocupar lugares públicos sem, todavia ser estereotipadas como personagens permissivas. As mulheres goianas encararam a Igreja Católica, uma instituição de disciplinamento, como um refúgio ou mesmo um espaço no qual podiam adquirir certa autonomia, aspecto de suas vidas que nem sempre era considerado pela sociedade e pela família. (Prado, 20।4:23)

4 Acervo do Gabinete Literário Goiano, Goiás-GO. 
Embora os costumes do luto fossem bastante rígidos na Goiás de meados do século $X X$, onde um "riso ou mesmo uma expressão um pouco mais alegre eram suficientes para que a pessoa enlutada fosse duramente comentada" (Albernaz, 1992: 34), acreditamos ter sido esta uma oportunidade de as mulheres se apropriarem de responsabilidades que jamais teriam caso seus esposos permanecessem vivos. Deste modo, a morte, mesmo trazendo dor e clausura, era também libertadora.

Ainda que persistisse a imagem de que a elas cabia apenas guardar a dor da perda ou serem depositárias das memórias familiares, convencionalmente regida pela figura masculina, Ariès (20I2) deixou registrado algumas questões referentes ao caráter construído deste sentimento de perda entre as mulheres. Foram os estudos de gênero e de história das mulheres que apontaram o peso das mudanças ocorridas no século XIX e que imbuíram as mulheres, principalmente aquelas pertencentes a segmentos sociais abastados, desse e de tantos ofícios no interior do lar.

Conforme Maria Ângela D'Incao,"considerada base moral da sociedade, a mulher de elite, a esposa e mãe da família burguesa deveria adotar regras castas no encontro sexual com o marido, vigiar a castidade das filhas, constituir uma descendência saudável e cuidar do comportamento da prole" (201 I: 230). Acrescentamos aqui a função de guardiã de memórias e do luto, caso perdessem seus maridos, como aconteceu com Jacintha Luiza.

Consideramos que o gênero tenha operado em muitos seguimentos da vida social de mulheres viúvas, obrigando-as a tornarem-se responsáveis, dentre várias coisas, da memória de seus mortos. O fato de haver resquícios de proibições que as impediam de desempenhar atividades remuneradas ou sair para desenvolver suas influências junto às portas do poder as incumbia, por exemplo, da guarda de memórias ancoradas em fotografias, objetos e roupas.

"Fotografias de crianças sérias e bem-comportadas, de calçotes de babados sobressaindo nas barras dos vestidos rufados" (Coralina, 2006: 92), "retratos notáveis de gente circunspecta, sisuda e barbada em trajes e atitudes superadas" e aqueles de "mulheres com seus manteletes, miternes, grandes leques, saias de meranaque deixando ver a pontinha da botina" (2006: 92) serviram e servem de meios nos quais estas duas mulheres, em sua ancianidade vigorosa e sã, depositaram memórias e reminiscências interseccionadas pelo luto.

A sobrevivência dessas fotografias evidencia como a recordação pode "tornar-se uma força política que erige normas capazes de contrapor-se ao presente" (Assman, 20 I I: I 83). Conforme Aleida Assmann esta força depositada em "espaços de recordação" opera de modo a superar o presente mau e cria o novo tempo, sem, todavia, romper o "elo com os mortos" (Queiroz, 20I4: I4) e com o passado.

A guarda desses "meios" de recordação serve de força que auxilia na superação da dor do luto, ajuda a instalar um novo tempo marcado pela saudade e denuncia marcas de gênero, pois o exercício de guarda de fotografias e de coisas, frequentemente dirigido às mulheres, nos força provocar quais dispositivos de poder as elegeram como guardiãs da memória e do luto.

Seria o fato de permanecer nos vilarejos, guardando a "terra que elas ex- 
Museu Casa de Cora Coralina e o luto estratificado em memórias femininas

ploram e as tradições, a ponto de parecer arcaicas aos que retornam da cidade" (Perrot, 2005: 296)? Seria algo resultante da mudança de costumes e hábitos, depois de instalado o romantismo no século XIX e que nutria o drama das exéquias entre pessoas próximas da família e o "culto exaltado da lembrança" (Ariès, 2012:231)?

É claro que nossa intenção não é construir uma narrativa que determine ser apenas as mulheres enviuvadas guardiãs de memória e de coisas. Não é nossa intenção enxergá-las como agentes passivas e que ao enviuvar foram automaticamente imbuídas de guardar o luto. Não necessariamente o fato de enviuvar-se determinava a guarda do luto e de coisas evocativas de tal sentimento. Sobre isto, Ariès (20I2) foi bastante claro quando demonstrou exemplos históricos em que homens sofriam a dor da perda, subvertendo convenções de gênero. Ou mesmo do caráter efêmero e histórico das formas de luto e do manuseio da morte.

Acreditamos que considerar natural o exercício de guarda da memória por mulheres viúvas as engessaria em um discurso unilateral de gênero e que as pretende manter numa condição de subalternidade.

Aqui vale provocar o caráter ambivalente da guarda de memórias e do luto feminino. Apontamos isto porque ao tornarem-se viúvas muitas passaram a responder pelo patrimônio ou pelas dívidas de seus esposos, consequentemente elas passaram a ter patrimônio ou responsabilidades anteriormente compreendidas como masculinas. Deste modo, como poderíamos aprisioná-las passivamente numa categoria de guardiãs, se elas poderiam, à sua escolha, usar de forma libertadora algo que convencionalmente lhes parecesse castrador? Ainda cabe perguntar: Enviuvada a mulher guarda o luto e as coisas evocativas da memória do morto?

Acreditamos não ser por ai o entendimento do exercício de guarda de memórias por mulheres. A impressão que temos é a de que tudo isto seja interseccionado pelo gênero. $A$ guarda de memórias é uma questão acondicionada por marcas de gênero em que a construção histórica do leque de simbolismos sexuais impôs às mulheres tarefas relativas à exteriorização da dor da perda (Ariès, 20I2). Porém, a exteriorização deste sentimento não é algo dado, natural e determinante. Se entendêssemos que toda mulher viúva guarda o luto como poderíamos explicar a tranquilidade da personagem viúva, de Cora Coralina, "A viuvinha"? ${ }^{5}$ Após enviuvar-se, a jovem Hermínia de Oliveira fez uma viagem pela Europa, gastou todo o soldo da herança deixada pelo defunto e já articulava um novo matrimônio.

Esta crônica e outras informações referentes às mulheres nos forçam observar a manipulação de memórias e o exercício de guarda do luto de forma cultural, social e histórica. O luto não é algo pronto e acabado, mas uma construção histórica que se altera conforme a dinâmica cultural e segue o ritmo de mudanças cotidianas.

\section{“Quando eu morrer, não morrerei de tudo"}

Possivelmente ao guardar memórias do luto, Jacintha e Cora estavam

5 A Viuvinha. Goyas anno XXIV. Sábado I ago 1908, pp.3-4. 
guardando fragmentos com os quais se identificavam. Elas guardaram memórias que as permitiam acessar tempos outros e a própria identidade. Precisamos que talvez isto fosse até uma imposição, uma violência de gênero historicamente ditada por normas apegadas aos dispositivos de controle de suas sexualidades no interior da família e da sociedade.

A partir de Jacintha Luiza e Cora Coralina acreditamos ser importante considerar questões relativas ao gênero, à condição das mulheres no interior da simbolização de seu sexo, as questões referentes ao mundo conjugado em um modelo humano neutro e universal (Scott, 2008) e que, por sua vez, era/é influenciado pelo sexo da dominação (Correa, 1999).

O fato é que outra forma de encenar a imortalidade consistiu no registro literário dessas memórias do luto. Apesar de dizer em entrevistas não se importar com a imortalidade simbólica e que "o que vale é a imortalidade da carne, dos músculos, dos ossos, da massa cinzenta” (In: Borges, 2004), observamos que Cora Coralina dedicou parte de sua vida à busca da imortalidade por meio de suas obras. Em diversos poemas encontramos esse anseio, a exemplo do verso que intitula este item que reafirma que quando morrer não morrerá de tudo já que estará nas páginas de seus livros. Aqui dialogamos com Alessandra El Far (2000) ao concebermos tais estratégias autorais como mecanismos de "encenação da imortalidade", garantindo a sobrevivência de determinadas memórias e, por isso mesmo, a invenção de tradições.

Em sua obra existem inúmeras passagens sobre a morte, a guarda do luto e estratégias de encenação de imortalidades a partir da escrita e da guarda de objetos: os "brincos rebuçadinhos de preto, dizendo luto permanente" (Coralina, 2007: 58); a "veste preta, rebuço preto de cabeça e mais umas chinelas pretas" (2002: 32); ou as "cartas e mais cartas enfeixadas, amarradas, coordenadas. Certos maços eram atados com fitas pretas, dizendo luto.” (2006:90)

Além de seu conteúdo, a materialidade do acervo pessoal aciona memórias de e sobre Cora Coralina contribuindo para a fabricação de determinados repertórios sobre a personagem e, por isso mesmo, articulando valor econômico e simbólico. A gestão do legado consiste em promover a vida e obra da autora, reatualizando e ritualizando determinadas versões construídas por ela e por outros agentes de acordo com os interesses dos herdeiros, das instituições de guarda e do campo literário vigente. Nesse aspecto, é fundamental vislumbrar a ação do Museu Casa de Cora Coralina na produção/consolidação da sua memória biográfica. (Delgado, 2005)

$\mathrm{Na}$ verdade, a exposição museológica consiste em uma operação de monumentalização composta por múltiplas camadas de memórias. A própria existência de um museu-casa em sua homenagem implica uma tentativa de vencer o esquecimento. Em outras palavras, a musealização como prática seletiva contribui para observarmos os embates em torno da não-patrimonialização, para o apagamento de determinadas memórias ou para que se torne um lócus de resistência a outras práticas discursivas. Em primeira instância são essas retóricas da perda (Gonçalves, 1996) que integram os conflitos, pautadas na eleição e promoção de determinadas memórias que estariam em risco de desaparecimento, em detrimento de outras. Visto sobre esse prisma, a tensão dramática seria elemento constitutivo da poética dos museus. 
Museu Casa de Cora Coralina e o luto estratificado em memórias femininas

Conforme destacou Aparecida Rangel, no museu-casa o drama é evidenciado,"sobretudo em função da ausência física de seu objeto mais proeminente, ou seja, o personagem que lhe dá sentido, o anfitrião do espaço. Na realidade, esse tipo de museu nasce a partir da morte" (2007: 8I). Talvez, por essa razão, o "consumo do trágico" esteja tão presente nessas exposições museológicas como uma das formas de produção da crença na intimidade, na superação das adversidades e no heroísmo. Os museus, ao encenarem a imortalidade, venceriam a morte através do culto a certos objetos e personagens do passado, afirmando-os no presente (Abreu, 1996) a partir da seleção de mecanismos para o estabelecimento de uma "presença dos ausentes" (El Far, 2000).

Os museus se apresentam como uma das formas de encenação da imortalidade, visto que o colecionismo "está de algum modo associado ao medo da morte ou à necessidade de se manter vivo, em memória, através dos objetos colecionados, sejam eles quais forem. (...) Um indivíduo estará realmente morto quando ninguém mais se lembrar dele" (Queiroz, 20I4:49). A musealização de eventos críticos e a patrimonialização da dor também podem ser recuperadas nas interfaces entre memória e morte, ou, na argumentação de Marijara Souza Queiroz (20/4), na necrofilia dos museus. Nossa hipótese é que existe uma forma peculiar de guarda dessa memória quando a olhamos sob o prisma do gênero.

Existiria uma expectativa de performance a ser realizada pelas mulheres ao "guardar o luto" no espaço doméstico e, especialmente, no espaço público a partir de um código estético:

\begin{abstract}
No início da República a mulher educada e casada enviuvada teria que enfrentar um certo código estético e de disciplinamento inerente as limitações da viuvez. Uma série de comportamentos de reclusão social, de interiorização no privado demonstrando o recato, como etiqueta conveniente e demonstração de respeito à memória do cônjuge falecido exigia dela o cumprimento do luto, prática social que impunha não só trajes mais sóbrios, de preferência o preto, por um ano, como uma gestualidade contida e pouca demonstração de alegria. (Possas, 2008: I-2)
\end{abstract}

O fato é que ao serem destinadas ao privado, as mulheres tornaram-se as grandes responsáveis por preservar e edificar a memória familiar, especialmente manifesta a partir de documentos escritos, fotografias e objetos. Isso é evidente no caso da memória da morte sendo reincidente o papel de guardiãs de fotografias mortuárias, roupas e outros objetos relacionados ao ancestral falecido. Conforme observamos, isso consistiu em uma das marcas da trajetória de Jacintha Luiza e de sua filha Cora Coralina. Cora herdou essa cultura material de sua mãe, tornando-se responsável pela manutenção desses marcadores de luto, instituindo uma intensa batalha contra o esquecimento. Talvez porque a viuvez também demarcasse relativa autonomia na vida das mulheres que sem a presença masculina eram obrigadas a se enveredar na cena pública para seu sustento e de sua família. 
Nesse caso, a viuvez e o luto consistiam em um rito de passagem que demarcaria uma maior presença no espaço público, conforme ocorreu com Jacintha em sua tripla viuvez e, posteriormente, com a própria Cora. (Britto; Seda, 2009). O fato é que nas trajetórias dessas mulheres o luto foi reapropriado e utilizado como moeda simbólica no espaço público. Com a viuvez obtiveram maior autonomia financeira e intelectual, conquistaram de algum modo "um teto todo seu" para a configuração de sua atuação na cena intelectual de Goiás, tornando-se mulheres públicas (Perrot, 1998).

O luto representado em fotografias e objetos consiste em uma forma de evidenciar as memórias de saudade, dor e também de libertação. Jacintha colecionou um conjunto desses elementos, especialmente fotografias mortuárias legando-as a Cora Coralina que, por sua vez, as manteve preservadas e, atualmente, permanecem sob a guarda do Museu-Casa de Cora Coralina.

De acordo com Sandro Blume, a presença da fotografia nos rituais da morte contribuía no processo de elaboração do luto, além de atestar e perpetuar determinadas imagens do ente querido, informando que "geralmente se recorria de forma mais emblemática às fotografias pós-morte quando o falecido ainda não tinha sido retratado em vida" (2013: 2), a exemplo do pai de Cora Coralina e de outras fotos mortuárias colecionadas pela poeta e que estão na reserva técnica do museu-casa. Destaca, ainda, que nos dias de hoje a exibição dessas fotografias gera uma série de constrangimentos para os detentores desses acervos, considerados como de teor macabro:"igualmente aos olhares contemporâneos, a fotografia mortuária parece prolongar a dor, sendo percebida, até mesmo pelas famílias que preservam tais fotografias, como uma atitude mórbida, em função de fixar a morte como elemento de recordação.” (20l3: 3)

Caso exemplar consiste na fotografia mortuária de Francisco de Paula Lins dos Guimarães Peixoto, segundo marido de Jacintha e pai de Cora Coralina, que a poeta emoldurou e colocou na parede de sua residência desde a década de 1970. Conforme destacou Andrea Delgado, uma informação relevante é o fato da própria Cora ter emoldurado esses objetos, arranjando-os cuidadosamente e colocando-os ao olhar público:"a combinação da fotografia do pai, com a imagem de Padre Cícero, a fotografia de Lampião e seu bando e o arranjo de flores artificiais confere, ao mesmo tempo, 'valor de culto' e 'valor de exposição' ao conjunto iconográfico" (2003: 97), tornando-se, nesse aspecto, espécie de altar doméstico, evocativos de uma memória ancestral nordestina.

Andrea Delgado (2003) é quem desenvolve essa idéia transcrevendo um depoimento de Cora Coralina gravado na sessão da Academia Feminina de Letras e Artes de Goiás, em 10 de junho de 1980:

$\mathrm{Na}$ minha casa eu tenho um pôster de Lampião e a turma de Lampião, inclusive Maria Bonita, e tenho Padre Cícero. E digo:'porque eu tenho Lampião, por quê?' Muita gente pergunta: 'a senhora conheceu?' Eu digo:'não. Ele nunca veio a Goiás e eu nunca fui ao Nordeste'. Mas digo a vocês, faço as minhas orações pela alma de Lampião e dos seus companheiros. Faço por honra de Maria Bonita e já não rezo pelo Padrinho Cícero. Representa-me dentro de mim que ele não carece de orações, já é santificado. (In: Delgado, 2003: 97) 


\section{Museu Casa de Cora Coralina e o luto estratificado em memórias femininas}

$\mathrm{Na}$ tessitura poética empreendida por Cora Coralina (Fig. I) e mantida nas exposições museológicas, as figuras de Lampião, Maria Bonita e cangaceiros, aliadas a imagem de Padre Cícero, se tornam suportes para recuperar uma memória do pai que ela conheceu apenas pela memória familiar, pela fotografia e por alguns objetos sobreviventes: "Um grande cabide mancebo, onde jazia pendurado um velho cavu preto, que tinha sido de meu pai, todo cheio de abas e recortes, forrado de alpaca de seda com marca de Londres. [...] Conheci também na casa uma cartola de pêlo, de meu pai. (Coralina, 2006:89)

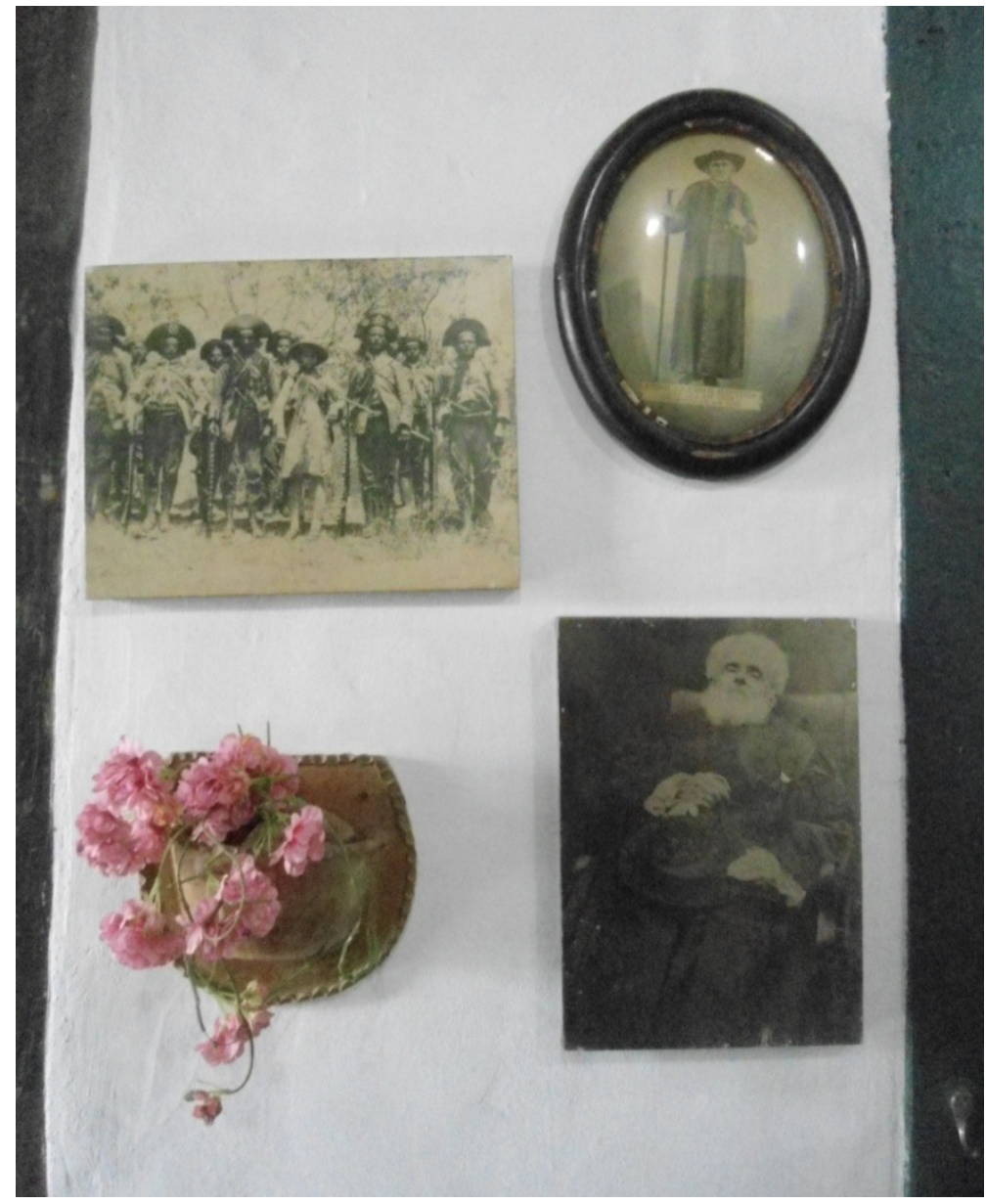

Fig. I - Quadros organizados por Cora Coralina. Foto: Clovis Britto, 2009.

As imagens vistas em conjunto seriam uma forma de homenagear o pai, que faleceu quando Cora Coralina tinha poucos dias de nascida, constituindo em espaço de representação de uma falta. Por outro lado, o fato de expor a imagem consistia de um modo de evidenciar a presença masculina em uma casa de mulheres. Trata-se, desse modo, de uma forma de ritualizar a violência simbólica, indício de como a dominação masculina era eficaz em um sistema de saneamento da sexualidade, especialmente em fins do século XIX e início do XX. Além disso, também indicia as demarcações das esferas pública e privada, remetendo à ausência de quadros com fotos de mulheres na casa e o espaço onde a foto mortuária masculina era apresentada, em local privilegiado na sala de visitas. 


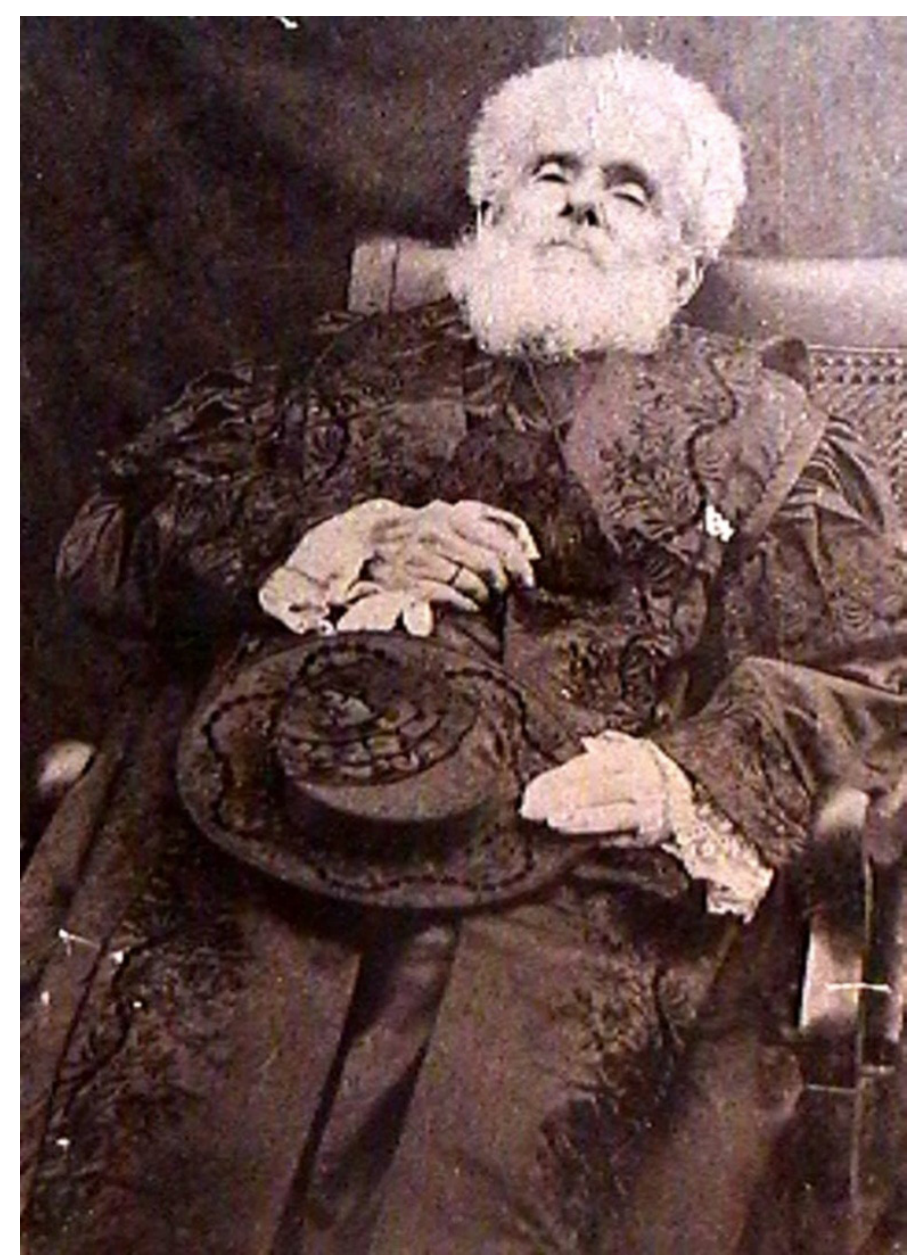

Fig. 2 - Detalhe do pôster com a foto mortuária de Francisco Peixoto. Foto: Rita Elisa Seda, 2009.

A exposição é montada para evocar a memória do pai da poeta, natural de Areia, na Paraíba. A foto exposta (Fig. 2) constitui em um evento crítico já que o apresenta morto, sentado em uma cadeira e vestido com sua toga, em 15 de outubro de 1889. A foto mortuária consiste em um indício do enlutamento, um acionador de uma memória trauma pessoal que se torna metáfora e metonímia de outras perdas, mas que também retoma o discurso de mulher que seguiu os preceitos da época, construindo família sob as bênçãos do sacramento do casamento e sendo devota ao esposo até post-mortem.

As mulheres, nesse aspecto, deveriam guardar o luto de modo mais severo, especialmente as viúvas. Isso resultava na preservação de objetos representativos do luto e, especialmente, portar uma memória no corpo manifesta na contenção e no luto vestimentar:"No caso das viúvas, deveria ser um sinal de afeição eterna e não segui-lo corretamente era interpretado como desprezo ao marido - uma ofensa imperdoável numa sociedade em que homens valiam muito mais que mulheres e eram responsáveis por sua posição social.” (Schmitt, 2009: 78)

No caso de Cora Coralina, guardar as fotos mortuárias consistia em re- 
Museu Casa de Cora Coralina e o luto estratificado em memórias femininas cuperar uma memória familiar expressa nas imagens dos entes representados, mas principalmente reverberar a memória materna, responsável pelo colecionamento e pela guarda. Trata-se de evidenciar uma memória de uma memória feminina que, por sua vez, traduzia um conjunto de práticas da maioria das mulheres goianas de camadas mais ou menos privilegiadas na virada do século XIX para o XX. Situação potencializada pela musealização dessas memórias que, em conjunto, consiste em uma tentativa de estratificar o luto, burlar a ausência e encenar a imortalidade.

\section{Referências}

ABREU, Regina. A fabricação do imortal: memória, história e estratégias de consagração no Brasil. Rio de Janeiro: Rocco, 1996.

ALBERNAZ, Ondina de Bastos. Reminiscências. Goiânia: Kelps, 1992.

ARIÈS, Philippe. História da morte no Ocidente: da Idade Média aos nossos dias. Rio de Janeiro: Nova Fronteira, 2012.

ASSMANN,Aleida. Espaços da recordação: formas e transformações da memória cultural. Campinas, SP: Editora da Unicamp, $201 \mathrm{I}$.

BLUME, Sandro. Fotografia mortuária: imagens da boa morte. Revista Brasileira de História das Religiões, Maringá/PR, v. 5, n. ${ }^{\circ}$ I5, jan. 2013.

BORGES, Rogério. Encontro inesquecível. O Popular, Goiânia, I 4 mar. 2004.

BOURDIEU, Pierre. A dominação masculina. Rio de Janeiro: Bertrand Brasil, 1999.

BRITTO, Clovis Carvalho; SEDA, Rita Elisa. Cora Coralina: raízes de Aninha. Aparecida, SP: Ideias e Letras, 2009.

CHAGAS, Mário. Memória e poder: dois movimentos. Cadernos de sociomuseologia. Lisboa, Portugal: Universidade Lusófona, n. ${ }^{\circ}$ 19, 2002.

CORALINA, Cora. Vintém de cobre: meias confissões de Aninha. 9 ed. São Paulo: Global, 2007.

Estórias da casa velha da ponte. São Paulo: Global, 2006.

O tesouro da casa velha. São Paulo: Global, 2002.

. Meu livro de cordel. Goiânia: Livraria e Editora Cultura Goiana, 1976.

CORRÊA, Mariza. O sexo da dominação. Revista Novos Estudos. São Paulo, SP: Centro Brasileiro de Análise e Planejamento (CEBRAP), n. 54, 1999.

CURY, Marília Xavier. Exposição: concepção, montagem e avaliação. São Paulo: Annablume, 2005.

DELGADO, Andrea Ferreira. Museu e memória biográfica: um estudo da Casa de Cora Coralina. Sociedade e Cultura, Goiânia, v. 8, n. ${ }^{\circ}$ 2, jul/dez 2005.

DELGADO,Andréa Ferreira. A invenção de Cora Coralina na batalha das memórias. Tese (Doutorado em História). Instituto de Filosofia e Ciências Humanas, Universidade Estadual de Campinas, 2003. 
D'INCAO, Maria Ângela. Mulher e família burguesa. In: PRIORE, Mary Del (Org.). História das mulheres no Brasil. São Paulo: Contexto, 2011.

EL FAR, Alessandra. "A presença dos ausentes": a tarefa acadêmica de criar e perpetuar vultos literários. Estudos Históricos, Rio de Janeiro, 2000.

GIORGIO, Michela de. O modelo católico. In: DUBY, Georges; PERROT, Michelle. História das mulheres no Ocidente:Vol.IV. O Século XX. Porto: Edições Afrontamentos, 1991.

GONÇALVES, José Reginaldo Santos. A retórica da perda: os discursos do patrimônio cultural no Brasil. Rio de Janeiro: Editora da UFRJ, 1996.

KOSELLECK, Reinhart. Estratos do tempo: estudos sobre história. Rio de Janeiro: Contraponto: PUC-Rio, 2014.

PERROT, Michelle. As mulheres ou os silêncios da história. Bauru, SP: EDUSC, 2005.

PERROT, Michelle. Mulheres públicas. São Paulo: Fundação Editora da UNESP, 1998.

PESAVENTO, Sandra Jatahy. Com os olhos no passado: a cidade como palimpsesto. In: PELEGRINI, Sandra de Cássia Araújo; ZARINATO, Silvia Helena (Org.). Narrativas da pós-modernidade na pesquisa histórica. Maringá: Eduem, 2005.

POSSAS, Lídia. Mulheres e Viuvez: recuperando fragmentos, reconstruindo papéis. Anais do Fazendo Gênero, Florianópolis, 2008.

PRADO, Paulo Brito do. Entre o perfume de angélicas e estrelas do norte as mulheres tornam perpétua a tradição do Perdão: por uma história (fé) minina em terras goianas nos séculos XIX e XX. In: BRITTO, Clóvis Carvalho; SIQUEIRA, Guilherme Antônio de; PRADO, Paulo Brito do. Por uma história da saudade: itinerários do Canto do Perdão na cidade de Goiás (Séculos XIX e XX). Goiânia: Gráfica e Editora América, 2014.

QUEIROZ, Marijara Souza. Museu, memória e a morte: um estudo a partir da coleção de quadros de cabelos da Fundação Instituto Feminino da Bahia. Dissertação (Mestrado em Artes Visuais). Salvador, BA: Universidade Federal da Bahia, 2014.

RANGEL, Aparecida.Vida e morte no museu-casa. Revista Brasileira de Museus e Museologia, IPHAN, n. 3, 2007.

SCHMITT, Juliana Luiza. A dor manifesta: vestuário de luto no século XIX. Dobras, v. 3, n. ${ }^{\circ}$ 5, 2009.

SCOTT, Joan Wallach. Género e historia. México: FCE, Universidad Autónoma de le Ciudad de México, 2008. 